\title{
Developing an Australian Code of Construction Ethics
}

Sean Francis McCarthy, (ACT Government Solicitor, Australia)

\begin{abstract}
This article looks at the increasing need to consider the role of ethics in construction. The industry, historically, has been challenged by allegations of a serious shortfall in ethical standards. Only limited attempts to date in Australia have been made to address that concern. Any ethical analysis should consider the definition of ethics and its historical development. This paper considers major historical developments in ethical thinking as well as contemporary thinking on ethics for professional sub-sets. A code could be developed specific to construction. Current methods of addressing ethics in construction and in other industries are also reviewed. This paper argues that developing a code of ethics, supported by other measures is the way forward. The author's aim is to promote further discussion and promote the drafting of a code. This paper includes a summary of other ethical codes that may provide a starting point. The time for reform is upon us, and there is an urgent need for an independent body to take the lead, for fear of floundering and having only found 'another debating topic' (Uff 2006).
\end{abstract}

Keywords: Ethics, Construction law

\section{Why construction ethics?}

In general terms the construction industry endures a poor reputation. This is not limited to Australia. A good many countries suffer the plight best summarised by U.K. academic Professor John Uff (2003) who has said there is a 'lack of trust and confidence between those involved in the construction process'. Australia faces a similar challenge - a 2003 study by the Queensland University of Technology (Zarkada-Fraser et al 1998) addressing construction ethics specifically stated 'In contrast with architects, however, construction contractors have a reputation for unethical behaviour, the main problem being, according to a poll conducted by the Journal of Building Research and Information, the high level of disputes between proprietors and builders'.

Ethics generally, have also been recently controversial. Whether questioning the morality of 'News of the World' phone hacking scandals, the blatant disregard for business ethics with the likes of Enron and $\mathrm{HIH}$ collapses, or sham contracting in the construction industry, there exists the eternal question of what the role ethics can play in any industry.

Many other industries have adopted their own code of behaviour or set of industry specific ethical values. Something can be gained from examining the various sector specific measures, for example in business ethics. In terms of construction specific measures the lead taken by the United Kingdom in developing a national Statement of Ethical Principles (by the U.K. Society of Construction Law) provides a fine example of how Australia might develop our own set of standards.

Australia is behind in both its research and the implementation of an industry standard. The very question of 'why it should be supposed that ethics would have any application to the field of construction law' has been answered by the UK Society of Construction Law (Uff 2003), and suggests the following reasons: 
1) The need for regulation in areas not covered by legally enforceable duties (with medicine as a prime example).

2) Because aligned industries to construction (engineering, architecture, surveying) all promulgate well developed ethical systems and regulation of professional conduct.

3) Because ethics is inferred (or should be) in many construction activities such as tendering and dispute resolution.

The distinctly English approach taken by Uff (2003) holds that 'An ethical approach may hold the key to a number of problems which have beset the construction industry for many years and may lead to a fairer and ultimately more prosperous future'.

\section{Specific Challenges in Construction Projects}

Construction projects provide many opportunities for ethical dilemmas to arise. Some of those stages have been identified as:

1. Contract documentation;

2. Obtaining tenders / placing contracts;

3. Construction; and

4. Post-construction.

Research in both Australia and South Africa has identified specific unethical conduct such as corruption, negligence, bribery, conflict of interest, bid cutting, under bidding, collusive tendering, cover pricing, frontloading, bid shopping, withdrawal of tender and payment games as concerns in construction (Hamzah Abdul-Rahman et al 2010).

\section{Australian Construction - a Brief History}

The industry in Australia has historically tended to be the domain of State and Territory Governments, however there has been an increasing trend since the 1960's for co-operation and consistency at the national level. Measures such as The Building and Construction Industry Improvement Act 2005 (Cwth) and the Implementation Guidelines for the National Code of Practice for the Construction Industry (August 2009) are examples of a more unified approach.

In August 2001 the Cole Royal Commission was established to report on the nature and extent of unlawful and inappropriate conduct in the building and construction industry. Its final submission in 2003 outlined a general disregard for the law, and also established that regulatory bodies in the industry had inadequate powers to enforce the law. As a result of the Commission, the Building Industry Taskforce was established in October 2002, as an interim measure prior to the development of a national authority. Over some 35 months of operation, the Taskforce received 3367 enquiries, undertook 500 investigations and placed 29 matters before the courts. That Taskforce tabled their final findings in September 2005 and 2006, with Mr Nigel Hadgkiss stating:

'This document highlights the continuation of unlawful and inappropriate behaviour in the industry' (Building Industry Taskforce 2005).

The report also quoted the following:

- 'You have to cheat to compete'

- 'Rule of law needs to be established in the industry'

- 'The industry remains plagued by a culture of civil disobedience, coercion, intimidation, threatening behaviour, and contempt for the law' 
- 'Incidences of inappropriate industrial pressure, which can, in many instances, involve violent and thuggish behaviour, contribute to the lawless culture that currently plagues the industry'

The Taskforce's own inability to act as an enforcement agent for the law hindered progress, and suggested that intimidation, thuggery and illegal conduct in the industry might finally be tempered more effectively through the impending national authority of the Australian Building Control Commissioner (the ABCC - established October 1 2005). It was said 'that the industry was characterised by a widespread disregard for the law', and it was thought that the ABCC could provide 'permanent and fundamental reform of the building and construction industry throughout Australia' (Building Industry Taskforce 2005). Further, it was thought 'The ABCC's enhanced powers and statutory function promises to be immensely effective in eliminating the culture of lawlessness from the industry.'

Initially the $A B C C$ was established to ensure compliance with workplace relations laws, but now 'devotes considerable resources to promoting proper conduct'. It defines one of its 'responsibilities' as assessing and referring matters to the appropriate government bodies including the Director of Public Prosecutions and the ACCC. It also investigates breaches of the Building and Construction Industry Improvement Act 2005 (BCII Act) and the building code. It assists with independent contractor legislation, can intervene in court proceedings involving building industry participants, can investigate breaches of collective agreements and awards, and provides assistance with the application of related legislation. It can enforce Commonwealth Acts and Regulations (ABCC website 2012). Where the ABCC suspects breaches, the $A B C$ Commissioner is also able to take legal action.

In terms of ethics, there is no one central authority charged with its promotion.

\section{Defining Ethics}

Ethics is difficult to define without some consideration of a broader morality. Morality can be thought of as 'conforming to a conventional standard of moral conduct' (Collins Dictionary 1991). A 'moral' refers to a 'distinction between good and bad or right and wrong' (Collins Dictionary 1991). Ethics is 'a set of principles considered correct' and the 'social, religious or civil code of behaviour considered correct' (Collins Dictionary 1991). Ethics might be thought of as a narrower sub-set of morality, perhaps reflected in a set of agreed principles for a particular profession, but nevertheless linked to the moral values held by a group, or society at large.

Whether ethics can be thought of as 'you know it when you see it', or 'you've either got them or you don't' (Loulakis 2003) seems over simplified. Perhaps ethical conduct in its simplest is 'doing the right thing when no-one is looking' (DeVries 2009).

\section{Early Ethics}

\section{Natural Law}

Early ethical thinking thought that doing the right thing was based in a belief in Natural Law. Philosophers such as Aristotle, Rousseau, Hobbes and Locke believed in a universal guiding principal that allowed humans to fundamentally know the difference between right and wrong. Despite slight variations in approach, 'the essence of natural law may be said to lie in the constant assertion that there are objective moral principles which depend upon the nature of the universe and which can be discovered by reason' (Freeman 2008). Natural law proponents held that imminent truths existed and governed human nature, and mankind could essentially differentiate between right and wrong. Natural law rejected immoral values as illegal. 


\section{Bentham and Utilitarianism}

Utilitarianism developed ethical thinking beyond the omnipotent, with thinkers such as Austin and Hart taking a more cynical view and believing that humankind needed to have order imposed. Utilitarianism quantified the assessment of an outcome, with the most desirable choice providing the greatest good to the greatest number. Hence, an ethical dilemma could be solved by determining the greatest benefit and by providing the 'greatest happiness for the greatest number' (Rachels 1989). Bentham, for example considered a 'calculus of felicity' (Freeman 2008), measuring lots of happiness to ascertain what utility decreed.

\section{Positivism}

Thinkers like Fuller developed further the notion of a separate morality, and saw law as separate to mere belief and knowledge of what 'ought to be' (Freeman 2008). Some thinkers argued strongly over whether law should create moral obligations, especially for example if there existed an unjust law (for example apartheid or Nazi law). Hart argued that legal enforcement of morality must exist.

\section{Realism}

Ethical and jurisprudential philosophy developed with the approach of the Scandinavian Realists (1868-1939) who 'sought to reverse the general notion of moral standards as being embodied in the law by the idea that it is moral ideas that are themselves largely determined by the law' (Freeman 2008). The Scandinavian approach was logical given that legal prohibitions on murder and theft for example go back to earliest history. The Scandinavians argued the dissemination of legal, moral and religious decrees throughout history is impossible, and furthered the debate as to whether ethics determined law or law determined ethics.

\section{The Benefit of History}

Historical perspectives help highlight the question of whether ethics for construction practitioners can simply be known (a kind of Natural Law perspective), or whether society should intervene and impose legislation, a code or other means as intervention measures (a Positivism approach).

\section{Contemporary Ethics}

Contemporary ethics is also useful in considering how to approach ethics for construction. One such approach, Virtue Ethics, is cited as an example of 'one of three major approaches to normative ethics' (Oakley and Cocking 2001) and focuses on benevolence.

Virtue Ethics looks at the nature of a professional role and provides a 'fluid' approach to ethics, allowing for the particular circumstances of an ethical issue. It acknowledges the distinctiveness of each profession, and yet believes that a professional definition of ethics cannot be immune from society's broad based moral values.

Rather idealistically, Virtue Ethics believes internalised guiding ideals provide a basis for a professional moral framework (Oakley and Cocking 2001). It attempts to frame individual decisions in the context of an individual making a commitment to human good, and leading a 'flourishing life' through the application of good professional conduct. Virtue Ethics also emphasises moral education and industry specific frameworks for guiding those decisions.

Virtue Ethics believes that professional subsets of ethics can exist, and modern society now reflects that approach, perhaps confirming that modern ethical thinking has evolved well beyond a belief that good is known, to a belief that good can be directed. This is particularly relevant to the potential idea of developing a national code for construction ethics in Australia. 


\section{Professional Ethical Subsets}

Furthering the idea of professional subsets, a number of professions are increasingly turning to the development of a profession centric code of ethics or conduct. Widely criticised for a distinct lack of ethics (perhaps like construction), business ethics has been seen as an oxymoron. However, that does seem to be changing.

Controversial events in the business world have given rise to developments in the law to deal with director's responsibilities, ethical obligations and behavioural accountability. In business, the law itself is being used to impose ethical and behavioural standards, with serious criminal and pecuniary sanctions being applied to cases like HIH Insurance Ltd. Legislation such as the Corporations Act 2001 (Cwth) and even the Sarbanes-Oxley Act implemented in the U.S. address directors duties and establish ethical matters as law.

Business ethics, or the lack of, has been made famous by quotes such as:

- 'Enron actually had those values (respect, integrity...) well defined in it's own Code of Ethics handbook, but it appears the only time the board of directors ever paid attention to that handbook was when they were officially agreeing to disregard it' (Cruver 2003).

- Investigations into the Australian Wheat Board scandal stated that 'there is a need to mark out to employees of companies who hold office at the level of seniority of the offender that they have a social and moral obligation, as well as a statutory duty, to act honestly and responsibly' (Cole, the Hon T. 2006).

Whilst writers such as Carr (1988) believe the world of business accepts a distinct lack of ethics as a 'game plan', idealists such as Anshen (1998) still argue that business should reflect the broader values of society and should align business interests with other social interests. However, it would still seem many business professionals have been taught maximising shareholder wealth takes priority over 'unsexy' values such as integrity and respect (Cruver 2003).

Medical practitioners also have their own ethical subset in the form of the Hippocratic Oath. Doctors agree to respect the individual and to treat humans not diseases. Central to the oath is the notion that:

I will remember that I remain a member of society, with special obligations to all my fellow human beings, those sound of mind and body as well as the infirm.

In agreeing to adhere to the oath, medical practitioners arguably utilize a kind of moral framework as a guide to future actions. Providing that framework is a strong argument in favour of having such a code. Legal practitioners also take an oath to uphold justice and the Rule of Law. Legal practitioners commit to a duty to justice and the court first and foremost.

With business, medicine, the law and a variety of other professions developing industry specific codes of ethics or conduct, it is simply a logical progression that the construction industry in Australia should seek to develop their own code. As one US practitioner says:

The names Enron, Arthur Andersen, WorldCom, Global Crossing, and even Martha Stewart all invoke notions of greed and dishonesty. The construction industry, with its low-price mentality, stiff competition, and razor thin margins, presents a ripe environment for ethical dilemmas (Loulakis 2003).

Only to a limited extent in Australia has ethics for construction obtained some credibility as a stand alone concept. The Implementation Guidelines for the National Code of Practice for

McCarthy, S F (2012) 'Developing an Australian code of construction ethics', Australasian Journal of Construction Economics and Building, 12 (2) 87-100 
the Construction Industry (Australian Government Department of Education, Employment and Workplace Relations 2009) do broach good behaviour in stating:

'The core principles of the Code... are aimed at ensuring the industry:

- Is client focussed

- Is based on trust

- Observes ethical tendering

- Maintains standards of OHS and environmental practice

- Encourages responsible industrial relations'

\section{Developing a Code}

The lead of other regions is useful in benchmarking the Australian position with regard to construction ethics.

\section{Statement of Ethical Principles}

\section{Ethical conduct is the compliance with the following ethical principles.}

1. Honesty - act with honesty and avoid conduct likely to result, directly or indirectly, in the deception of others.

2. Fairness - do not seek to obtain a benefit which arises directly or indirectly from the unfair treatment of other people.

3. Fair reward - avoid acts which are likely to result in another party being deprived of a fair reward for their work.

4. Reliability - maintain up to date skills and provide services only within your area of competence.

5. Integrity - have regard for the interests of the public, particularly people who will make use of or obtain an interest in the project in the future.

6. Objectivity - identify any potential conflicts of interest and disclose the conflict to any person who would be adversely affected by it.

7. Accountability - provide information and warning of matters within your knowledge which are of potential detriment to others who may be adversely affected by them. Warning must be given in sufficient time to allow the taking of effective action to avoid detriment.

These principles apply to the work of all professionals working in the construction industry, whatever their original qualification or affiliation.

\section{Guidance on ethical principles}

\section{Application of statement}

The statement of ethical principles applies to persons as individuals, whether they work as an independent professional or as a partner, associate, director or employee of a firm or company.

Persons who work on behalf of a firm or company have additional responsibility to ensure that this statement of good practice is complied with by the firm or company to the extent of their authority.

\section{Legal and other duties}

The statement of good practice is in addition to any other professional code that may apply.

The statement of good practice is part of and additional to contractual and other duties taken on under civil law

The statement of good practice applies independently of any requirement imposed by or breach of criminal law.

\section{Unethical conduct}

Unethical conduct is the deliberate or reckless disregard for the ethical principles, as they would apply to the ordinary standards applicable to the activity being undertaken - the recognised practice in that profession. 


\section{The United Kingdom}

The U.K. Society of Construction Law has produced its own Statement of Ethical Principles. Given the apparent collaboration between the U.K. Society and the Australian Society of Construction Law, there may exist the opportunity for a good deal of cross-pollination to establish Australia's code.

With generally a wide acceptance it is, however, not necessarily the case that all practitioners or academics approve of the code, however. Jim Mason, for example from the University of the West of England, Bristol delivered a paper (using the U.K. Statement of Ethical Principles as the reference point) on 2-3 September 2010 in Paris suggesting that his studies into construction ethics would conclude a number of things, including;

1. Any effective ethical code needs to be less woolly and be more practical.

2. An ethical code needs a government backed enforcement body.

3. Ethics can only be addressed over the long term.

4. Partnering, publishing and using standard form contracts can all be effective methods of addressing ethics.

\section{The United States}

The United States has also sought to develop a code of ethics that can achieve industry wide acceptance.

\section{Construction Management Association of America Ethics Policy}

\section{CMAA Ethics Policy}

\section{Code of Professional Ethics for the Construction Manager}

Since 1982, the Construction Management Association of America (CMAA) has taken a leadership role in regard to critical issues impacting the construction and program management industry, including the setting of ethical standards of practice for the Professional Construction Manager.

The Board of Directors of CMAA has adopted the following Code of Professional Ethics of the Construction Manager (CODE) which apply to CMAA members in performance of their services as Construction and Program Managers. This Code applies to the individuals and to organizations who are members of CMAA.

All members of the Construction Management Association of America commit to conduct themselves and their practice of Construction and Program Management in accordance with the Code of Professional Ethics of the Construction Manager.

As a professional engaged in the business of providing construction and program management services, and as a member of CMAA, I agree to conduct myself and my business in accordance with the following:

1. Client Service. I will serve my clients with honesty, integrity, candor, and objectivity. I will provide my services with competence, using reasonable care, skill and diligence consistent with the interests of my client and the applicable standard of care.

2. Representation of Qualifications and Availability. I will only accept assignments for which I am qualified by my education, training, professional experience and technical competence, and I will assign staff to projects in accordance with their qualifications and commensurate with the services to be provided, and I will only make representations concerning my qualifications and availability which are truthful and accurate.

3. Standards of Practice. I will furnish my services in a manner consistent with the established and accepted standards of the profession and with the laws and regulations which govern its practice.

4. Fair Competition. I will represent my project experience accurately to my prospective clients and offer services and staff that I am capable of delivering. I will develop my professional reputation on the basis of my direct experience and service provided, and I will only engage in fair competition for assignments.

McCarthy, S F (2012) 'Developing an Australian code of construction ethics', Australasian Journal of Construction Economics and Building, 12 (2) 87-100 
5. Conflicts of Interest. I will endeavor to avoid conflicts of interest; and will disclose conflicts which in my opinion may impair my objectivity or integrity.

6. Fair Compensation. I will negotiate fairly and openly with my clients in establishing a basis for compensation, and I will charge fees and expenses that are reasonable and commensurate with the services to be provided and the responsibilities and risks to be assumed.

7. Release of Information. I will only make statements that are truthful, and I will keep information and records confidential when appropriate and protect the proprietary interests of my clients and professional colleagues.

8. Public Welfare. I will not discriminate in the performance of my Services on the basis of race, religion, national origin, age, disability, or sexual orientation. I will not knowingly violate any law, statute, or regulation in the performance of my professional services.

9. Professional Development. I will continue to develop my professional knowledge and competency as Construction Manager, and I will contribute to the advancement of the construction and program management practice as a profession by fostering research and education and through the encouragement of fellow practitioners.

10. Integrity of the Profession. I will avoid actions which promote my own self-interest at the expense of the profession, and I will uphold the standards of the construction management profession with honor and dignity.

Figure 2 The Construction Management Association of America Ethics Policy (reproduced with permission from CMAA)

\section{Other International Leads}

Construction ethics has also increasingly had focus in Asia and Europe. Major research in Malaysia revealed a lack of ethics to 'have a direct and negative impact on the quality of construction' (Hamzah Abdul-Rahman 2010) thereby furthering support that ethical conduct not only enhances reputational concerns, but has a direct impact on job quality and cost.

In a paper looking at the comparative approach of 8 European countries towards construction ethics, Professor Anthony Lavers surveyed participating countries over specific ethical issues. Laver built his study around the following potential questions:

1. Can a contract call for retention monies?

2. Can previous performance be evaluated in a current tender evaluation?

3. Could an architect switch from working for the owner to working for a contractor on the same project?

4. Can a client appoint a junior employee of his as contractor administrator of a traditional construction contract?

5 . Is a contractor obliged to warn of design defects?

6. Can a client have unlimited powers to terminate or vary a contract without good reason?

Laver concluded the study with a comprehensive summary of the relative position of the participating countries, and by saying that 'the most compelling conclusion of this exploratory exercise is that the individual Societies of Construction law can provide access to high quality information on construction law in the respective member countries and that the European Society of Construction Law is in a unique position to commission comparative research through its members'.

This creates a compelling argument that an equivalent organisation in Australia would be the logical base from which to launch our own unique code. 


\section{Australia}

With only limited national measures to date via Legislation and the Government Code of Practice, no one industry wide code has yet been implemented in Australia. Organisations with a relatively wide reach however, such as the Master Builders Association (the MBA) have established their own code in order to at least address ethics.

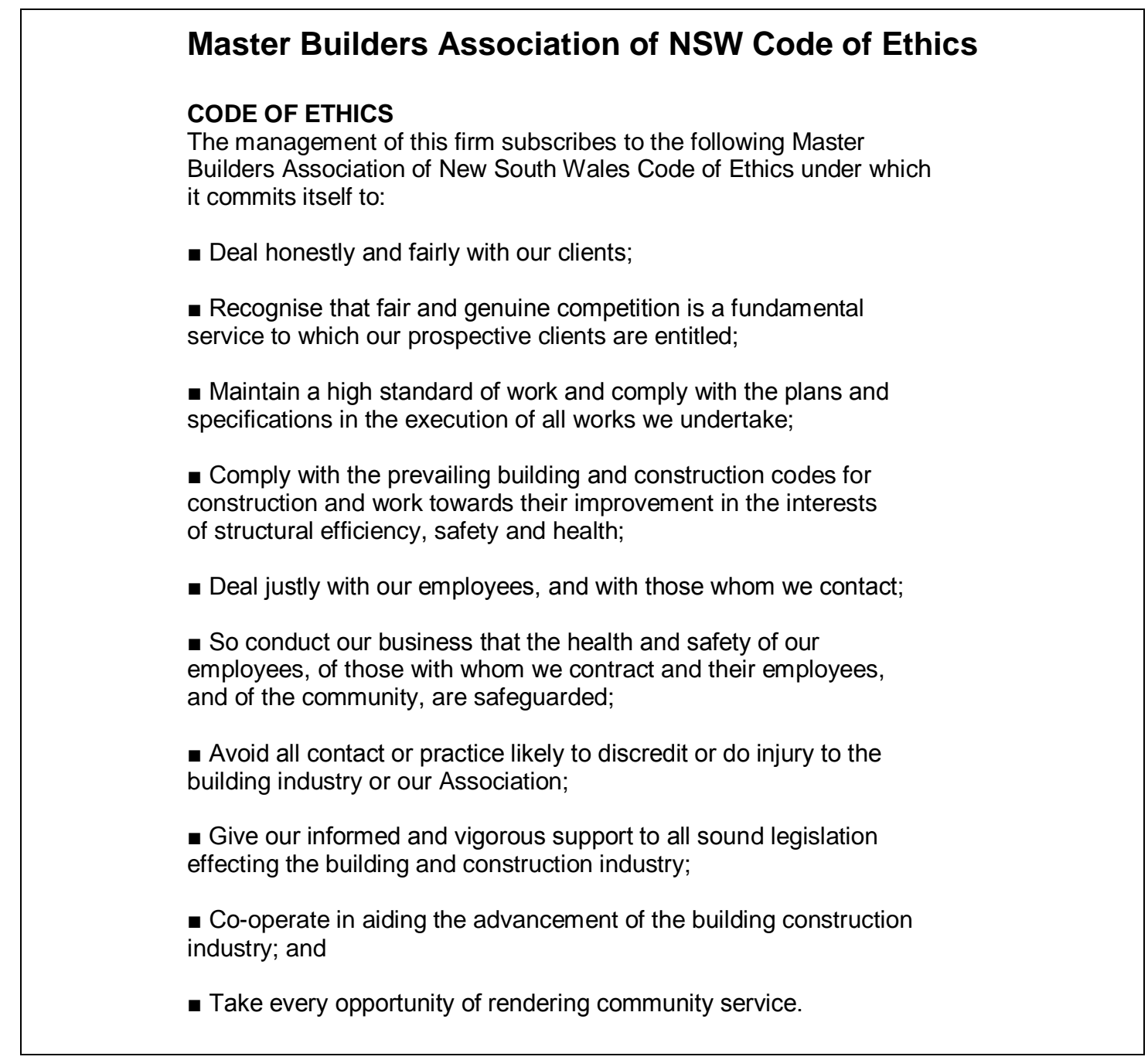

Figure 3 The MBA NSW Code of Ethics

(reproduced with permission 5 March 2012)

\section{Common Threads}

Summarising the essential elements from the various countries above (and the MBA code) arguably provides the initial steps towards outlining (at least) a code for Australia. That summary could provide a starting point as follows:

As construction industry professionals, practitioners will:

1. Act with honesty and without deception.

2. Act fairly so as not to obtain advantage.

3. Act with integrity and in the public interest.

4. Act with objectivity by identifying and addressing potential conflicts of interest.

5. Exercise professional diligence in standards of work and education.

6. Conduct themselves for the greater good of clients and society at large.

7. Notwithstanding the above, work for the interests of employees.

8 . Seek to improve the reputation of the construction industry.

McCarthy, S F (2012) 'Developing an Australian code of construction ethics', Australasian Journal of Construction Economics and Building, 12 (2) 87-100 
9. Comply with all relevant legislation and regulations.

10. Recognise and promote competition.

11. Act swiftly, and seek advice from an independent industry group on unresolved ethical matters.

\section{Supporting a Code}

\section{Industry Specific Legislation}

Further developments in the law may also be required to support the development of a code of ethics for the industry. The earlier cited Sarbane-Oxley Act of 2002 (U.S.A.) believes legislation might also help 'define the process by which corporations must conduct their business...' (Loulakis 2003).

However, in an industry already subject to a raft of legislation and regulations, more legal compliance may simply add to the complexity and make compliance more difficult. Certainly enforcement could be an issue. It may even be that 'No morality can ever be founded on authority, even if the authority were divine' (Ayer 1998), or that 'legality does not establish morality' (Pritchard and Robison 1979).

\section{Compliance Modelling}

In terms of how a code might be enforced, one step might be to consider the approach taken by the Australian Taxation Office (ATO) in promoting taxation compliance.

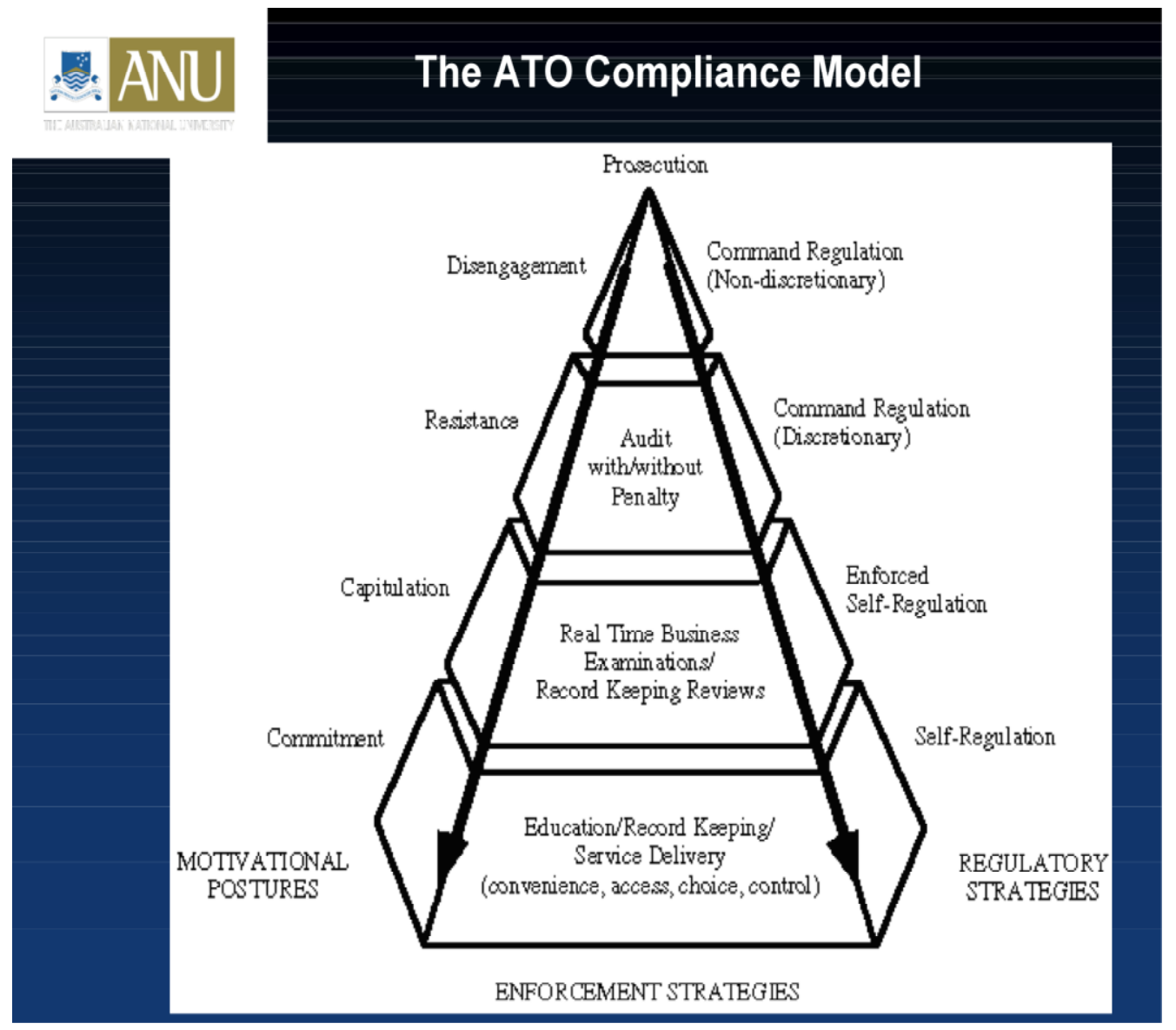

Figure 4 ATO Model of Compliance from "An Evolving Compliance Model for Tax Enforcement" by Valerie Braithwaite and John Braithwaite

Developed by John and Valerie Braithwaite (1992), a sliding scale of compliance is both logical and convincing. Central to its apparent success is a belief that "compliance is most

McCarthy, S F (2012) 'Developing an Australian code of construction ethics', Australasian Journal of Construction Economics and Building, 12 (2) 87-100 
likely when an agency displays and employs an explicit enforcement pyramid'. The ATO model imposes a hierarchy of enforcement measures starting from 'persuasion' on the lowest level, to 'licence revocation' (for taxation practitioners) at the top of the apex. The Compliance Model was developed to:

1. Understand the dynamics of the cash economy

2. Build partnerships with the community

3. Offer incentives for compliance

4. Enforce compliance on an elevating scale.

The model utilises increasing levels of enforcement (made known to taxation practitioners), starting at the lowest level with simple persuasion measures. Over time a series of stepped enforcement measures may be utilised, and culminate with the possibility of full criminal sanctioning for those in defiance of their responsibilities.

Having worked remarkably well, the sliding scale of compliance could be transposed to any industry, and would seem well suited to the construction industry. Initial compliance, for example, to an industry code of ethics, could be 'persuaded' by demonstrating wide acceptance and take up of the code, and for example could be enforced at tender stage. Compliance might elevate through mandatory education programmes for practitioners (for example on longer term or large scale projects), and increase to the highest level of compliance through law or contractual provisions.

\section{Education and Awareness}

Any ethical developments, whether by a code or not, must also be supported by education and awareness. In a study by QUT on Construction Management student's perception of ethics in tendering (QUT 1998) it was evident that 'The obvious stress on the need for profitability appears to generate a perceived conflict between profit and ethics, which is not resolved in the current curriculum'.

Empirically, ethical education works. Although not construction related, a survey by the Australian Institute of Chartered Accountants studied the benefits derived from on-going ethics education (O'Leary 2008). A study of 155 students exposed to five ethical dilemmas both before and after on-going education, revealed surprising results. Performed on students predicted to already have well formed ethical parameters at the outset, the authors stated, 'Well, we were wrong...in all five scenarios students selected a more ethical option after the ethical training than before...ethical instruction methods did have an affect on their attitudes and a positive one at that' (O'Leary 2008).

It may also be that education can link to practitioner registration. Following the lead that some Australian jurisdictions have taken towards domestic construction, it may be that a similar approach can be adopted in commercial construction. Uff has supported such a view in the U.K. stating 'I suggest some form of registration which is capable of being revoked or withheld by an appropriately empowered body' (Uff 2006). The key question, for all jurisdictions, is who becomes the 'empowered body'? In that regard it is interesting to note that the U.K. Society of Construction Law has shied away from that task, not seeing itself as an enforcement agency.

\section{Standard Form Contracts}

Further to the earlier view that a compliance model would utilise both low and high levels of enforcement, that higher level might be imposed through the use of an agreed code or behavioural standards being used in standard form construction contracts. This would then create some notional legal compliance as a standard term of contract. 
Whilst a host of difficult and complex legal arguments might arise as to what such a code may mean in a legal framework, even in its loosest form could be made to impose a duty for contracted parties to comply with 'ethical standards that may reasonably be expected by practitioners in the construction industry'.

\title{
Establishing the Code
}

Ross (2001) provides his perspective that codes cannot exist in isolation.

\begin{abstract}
Perhaps we are asking too much of ethical Codes. We have to recognise that such Codes, which are usually general principles, are only a beginning to ethical behaviour. The gaps are filled by: specific professional association rulings, disciplinary proceedings, statutes and case law (Ross 2001).
\end{abstract}

Even codes of conduct can take a legally binding form (such as the Franchising Code of Conduct), or may simply outline a set of idealistic professional standards as industry practice. Whilst to writers such as Ross (2001), 'Codes of professional conduct are one of the most important characteristics of a profession', to others they are more puzzling:

What is it exactly, and how can it bind us? Or can it? Its status, normative if not otological, seems mysterious. Either its pronouncements are obvious (read 'platitudinous'), in which case it invites ridicule, or they are not obvious (read 'controversial') in which case it arouses suspicion. A third possibility is that its pronouncements are vague. In that case they are useless unless interpreted. When interpreted, they are either obvious thus platitudinous; or not obvious thus controversial (Lichtenberg 1996).

However, a simple professional code does have numerous benefits such as establishing a framework for decision making; offering a sense of protection for members and consumers; showing a professional commitment to standards; imposing standards to aspire to for nonmembers, and; establishing professional solidarity. But they also have weaknesses. Codes can risk being ineffectual lip service; being remedial in nature; or serving only to try and give credibility to professions that have suffered. If poorly drafted, a code may not provide any framework for decisions.

Again following the U.K approach, Uff (2003) made it known that 'The task is to define a multi-disciplinary ethical code to apply to those performing a particular function (in construction) irrespective of their profession of origin'. Further, he held that a Code would cover 'the drawing up and awarding of contracts; the administration of contract performance; and the formulation of and resolution of claims and disputes'. Whilst not all of those issues are adequately covered, the U.K. Statement of Ethical Principles has gone some way towards addressing those concerns.

\section{Challenges in Establishing a Code - Who Steps Up?}

Arguably, the next step is simple - develop the code. The key question now is who will develop the code, and with what methodology? Will it simply be by reference to other codes, or by collaborative industry consultation? Ultimately, who will nail their name to the masthead as the organisation developing and promoting the code? There are obvious choices such as the Australian Society of Construction Law. That would seem a logical place for the responsibility to rest. The first stage however, would be (as with the U.K SoCL) the establishment of an 'Ethics Committee', which to date does not appeared to have occurred.

Ultimately we also face the challenge that confronted the U.K. in deciding who will enforce the code. If indeed, 'The quality of the moral behaviour varies in inverse ratio to the number of human beings involved' (Aldous Huxley from Grey Eminence, Ch.10), then time is of the essence in setting up the code. 


\section{Bibliography}

ABCC, Background; Legislation, from http://www.abcc.gov.au

Anshen, M. (1998) 'Changing the Social Contract: A Role for Business', Joan C Callinan (ed), Ethical Issues in Professional Life, Oxford University Press, New York

Australian Government Implementation Guidelines for the National Code of Practice for the Construction Industry, August 2009, Australian Government, Department of Education, Employment and Workplace Relations

Australian Society of Construction Law at http://www.scl.org.au

Ayer, A. J. (1998) 'Essay on Humanism', The Penguin Thesaurus of Quotations, Penguin Books

Braithwaite, V. \& J. (1992) 'An Evolving Compliance Model for Tax Enforcement' from http://vab.anu.edu.au/pubs/1/anevolvingcompliance.pdf

Building Industry Royal Commission: Background, Findings and Recommendations updated 25 September 2003, from http://www.aph.gov.au/library/pubs/CIB/2002-03/03cib30.htm

Carr, A. (1988) 'Is Business Bluffing Ethical?', Joan C. Callahan (ed.) Ethical Issues in Professional Life, Oxford University Press, New York

Cole, the Hon T. (2006) 'Report of the Enquiry into Certain Australian Companies in relation to the UN Oil-for-Food Programme: Summary recommendations and Background Commonwealth of Australia'.

Collins Dictionary (1991) Collins Publishing

Construction Management Association of America Code of Ethics from http://www.cmaanet.org/cmaa-ethics-policy

Cruver, B. (2003) Enron - 'Anatomy of Greed', Arrow Books

Freeman, M.D.A. (2008) Introduction to Jurisprudence, Sweet and Maxwell

Hamzah Abdul-Rahman, Chen Wang and Xiang Wen Yap (2010) 'How professional ethics impact construction quality: Perception and evidence in a fast developing economy', Scientific Research and Essays 5 (23)

Lavers, A. (2006) 'Ethics in Construction Law - A Review of the Position in Eight European Countries' a paper given to the European Society of Construction Law, Stockholm, 26 August 2006

Loulakis, M. (2003) 'Ethics in Construction: Challenges and Dilemmas', International Risk Management Institute (USA), 18 Nov 2003

Main, A. (2003) 'Other Peoples Money - The Complete Story of the Extraordinary Collapse of HIH', Harper Collins Publishers

Mason, J. 'A Single Ethical Code for the Construction Industry - What do Young Professionals

Mason, J. 'Promoting Ethical Improvement in the Construction Industry - A single Professional Code?' Department Of Construction and Civil Engineering University of the West of England, Bristol

Matteson, J. (2002) 'Constructing Ethics and the Ethics of Construction: John Ruskin and the Humanity of the Builder' from http:www.crosscurrents.org/matteson2002.htm

O'Leary, C. (2008) 'The Importance of Ethics' Charter Magazine, August 2008

Oakley, J. and Cocking, D. (2001) 'Virtue Ethics and Professional Roles', Cambridge University Press

Parson, E. (2005) 'The Construction Industry's Ethical Dilemma' from http://ecmweb.com/mag/electric construction industrys ethical/1 Aug 2005 
Pritchard and Robison (1979) 'Profits and Professions: Essays in Business and Professional Ethics', Humana Press

Rachels, J. (1989) 'What is Morality?' from James Rachels (ed) The Right Thing to Do, New York, Random House

Ross, Y. (2001) 'Ethics in Law', $3^{\text {rd }}$ ed, Butterworths

Rowland, T. L. 'Ethics in Construction: A Risk Management Issue' from http://www.irmi.com/.../ethicsinconstructionchallengesanddilemmas.pdf

Stanford Encyclopaedia of Philosophy (2007) Virtue Ethics at

http://plato.stanford.edu/entries/ethics-virtue/

The Penguin Thesaurus of Quotations (1998) Penguin Books

Think about it?' Department of Construction and Property University of the West of England, Bristol

U.K. Society of Construction Law at http://www.scl.org.uk

Uff Prof J CBE QC (2003) 'Duties at the legal fringe: Ethics in Construction Law' Centre of Construction Law \& Management - The Michael brown Foundation fourth public lecture delivered at The Great hall, Kings College London, 19 June 2003

Uff Prof $\mathrm{J}$ (2006) 'Ethics in Construction law - two years on' Australian Construction Law Newsletter \# 106, February 2006

Upholding the Law - Findings of the Building Industry Taskforce' Building Industry Taskforce, Sept. 2005, 1

Vee, C. and Skitmore, R. (2003) 'Professional ethics in the construction industry' from http://eprints.qut.edu.au/archive/00004119

Zarkada-Fraser, A. et al. (1998) 'Construction Management Students' Perceptions of Ethics in Tendering' QUT from https://eprints.qut.edu.au/secure/00004479/01/Bear98r1.doc

\section{Legislation and Regulations}

Building and Construction Industry Improvement Act 2005 (Cwth)

Building and Construction Industry Improvement Regulations 2005 (Cwth)

Trade Practices Act 1975 (Cwth)

The Corporations Act 2001 (Cwth) 